Chirurgia (2020) 115: 665-669

No. 5, September - October

Copyright@ Celsius

http://dx.doi.org/10.21614/chirurgia.115.5.665

\title{
Duplication of Inferior Vena Cava, Possible Cause of Internal Hernia? Literature Review and Rare Case Presentation
}

\author{
Cédric Kwizera', Daniel G. Popa ${ }^{1,2^{*}}$, Marian Botoncea ${ }^{1,2}$, Adrian Tudor ${ }^{1,2}$, György D. Száva1, Alexandru Strat ${ }^{1,2}$, \\ Călin Molnar ${ }^{1,2}$
}

${ }^{1}$ First Clinique of Surgery. Emergency County Hospital, Târgu Mureș, Romania

2“George Emil Palade” University of Medicine, Pharmacy, Science and Technology, Târgu Mureș, Romania

${ }^{*}$ Corresponding author: Lecturer, Daniel G. Popa MD, PhD

First Clinique of Surgery Emergency County Hospital

Târgu Mureș, Romania

E-mail: dan_popa70@yahoo.com

\section{Rezumat}

Duplicarea venei cave inferioare, posibila cauză a unei hernii interne? Revizuirea literaturii și prezentarea unui caz rar

Duplicarea venei cave inferioare este o malformație congenitală rară de extremă importanță pentru chirurgii vasculari, urologii şi radiologii intervenționişti. Deseori trece neobservată şi este diagnosticată incidental la o scanare CT de rutină sau de urgență atunci când apar complicații din cauza malformațiilor congenitale asociate. Vă prezentăm cazul unui pacient în vârstă de 70 de ani internat de urgență acuzând dureri abdominale care a fost diagnosticat cu ocluzie intestinală din cauza unei hernii paraduodenale stângi, asociată cu duplicarea venei cave inferioare. Revizuirea literaturii a condus la concluzia că duplicarea venei cave inferioare nu este cauza hernii paraduodenale stângi.

Cuvinte cheie: duplicarea venei cave inferioare, hernia paraduodenală stângă, ocluzie intestinală

\section{Abstract}

Duplication of inferior vena cava (DIVC) is a rare congenital malformation of extreme importance for vascular and urology surgeons, interventional radiologists. Oftentimes it goes unnoticed and is diagnosed incidentally at a routine or emergency CT-scan when complications occur due to associated congenital malformations. We present a case of a 70-year-old male patient who was 
admitted into the emergency room (ER) accusing abdominal pain. He was diagnosed with an intestinal obstruction due to a left paraduodenal hernia (LPDH), associated with a DIVC. The reviewing the literature led to concluding that DIVC is not the cause of LPDH.

Key words: duplication of inferior vena cava, left paraduodenal hernia, intestinal obstruction

\section{Introduction}

The inferior vena cava (IVC) develops during the $4^{\text {th }}$ and the $8^{\text {th }}$ week of gestation. Its intricate development can cause abnormalities such as posterior cardinal veins, subcardinal veins, supracardinal veins, persistent left IVC, DIVC, situs inversus, left retroaortic renal vein, left circumaortic renal collar, scimitar syndrome, and IVC agenesis which are incidentally diagnosed or in some cases can cause blood clots formation, abnormal blood flow, even back pain (1). DIVC is a rare vascular malformation of utmost importance for certain medical specialties such as vascular surgery, radiology, urology. Usually, it is discovered during retroperitoneal surgeries or during thromboembolic therapy (2). The incidence of DIVC is estimated between 0.2 $3 \%$ and oftentimes the differential diagnostics are retroperitoneal cyst or lymphadenopathy, aortic aneurism (3). DIVC can be associated with another rare congenital malformation of the gut namely an internal hernia (IH), a LPDH. In this paper, we want to find out if there is correlation and causation relationship between the two entities by reviewing the literature.

\section{Case report}

A 70 year-old male patient was admitted presenting intense abdominal pain, nausea, vomiting, loss of appetite. Physical examination revealed a distended abdomen, intense left hipocondrium and flank pain, accentuated epigastric and mesogastric tympanism, ileus and negative rectal examination. Personal history of high blood pressure and of varicose veins. Blood results showed leucocytosis $\left(12,87.10^{3} / \mu \mathrm{l}\right)$, neutrophilia $(86,88 \%$, respectively $\left.11,00.10^{3} / \mathrm{\mu l}\right)$ and hyperglycemia $(181,00 \mathrm{mg} / \mathrm{dl})$. An abdominal and pelvic CT-scan showed a proximal jejunum malrotation in the left hipocondrium/flank, distended and decalibrated small bowels with stasis and hydroaeric levels but no pneumoperitoneum. The preliminary conclusion was upper intestinal obstruction through a LPDH. CT-scan showed another congenital malformation: DIVC (Fig. 1). Axiphosubumbilical laparotomy was performed, adhesiolysis carried out. A normal ileum and entrapment with strangulation of the proximal jejunum was discovered (Fig. 2) in the left paraduodenal foramen (LPDF) (Fig. 3). Kelotomy was perfomed, the defect was closed with nonresorbable separated sutures, a subhepatic drainage inserted, abdominal wall closure performed along with skin suture and wound dressing. Postoperative recovery was uneventful, with food intake on day 4 , removal of subhepatic drainage and the patient discharge on postoperative day 8 .

\section{Discussion}

Embryologically, Bedel $\mathrm{C}$ et al. describes the most common theory or first theory based on a sequential and systematic development of IVC that takes place when there is regression of three paired veins. DIVC occurs when there is failure of regression of the left supracardinal vein early in gestation causing two large veins on either side of the aorta that oftentimes fuse frontward at the level of the renal arteries to become the suprarenal IVC and is usually associated with renal congenital malformations. There are 15 types of DIVC which mostly occur in animals but are rarer with a prevalence of $0.2-9 \%$ : the retroaortic left renal 


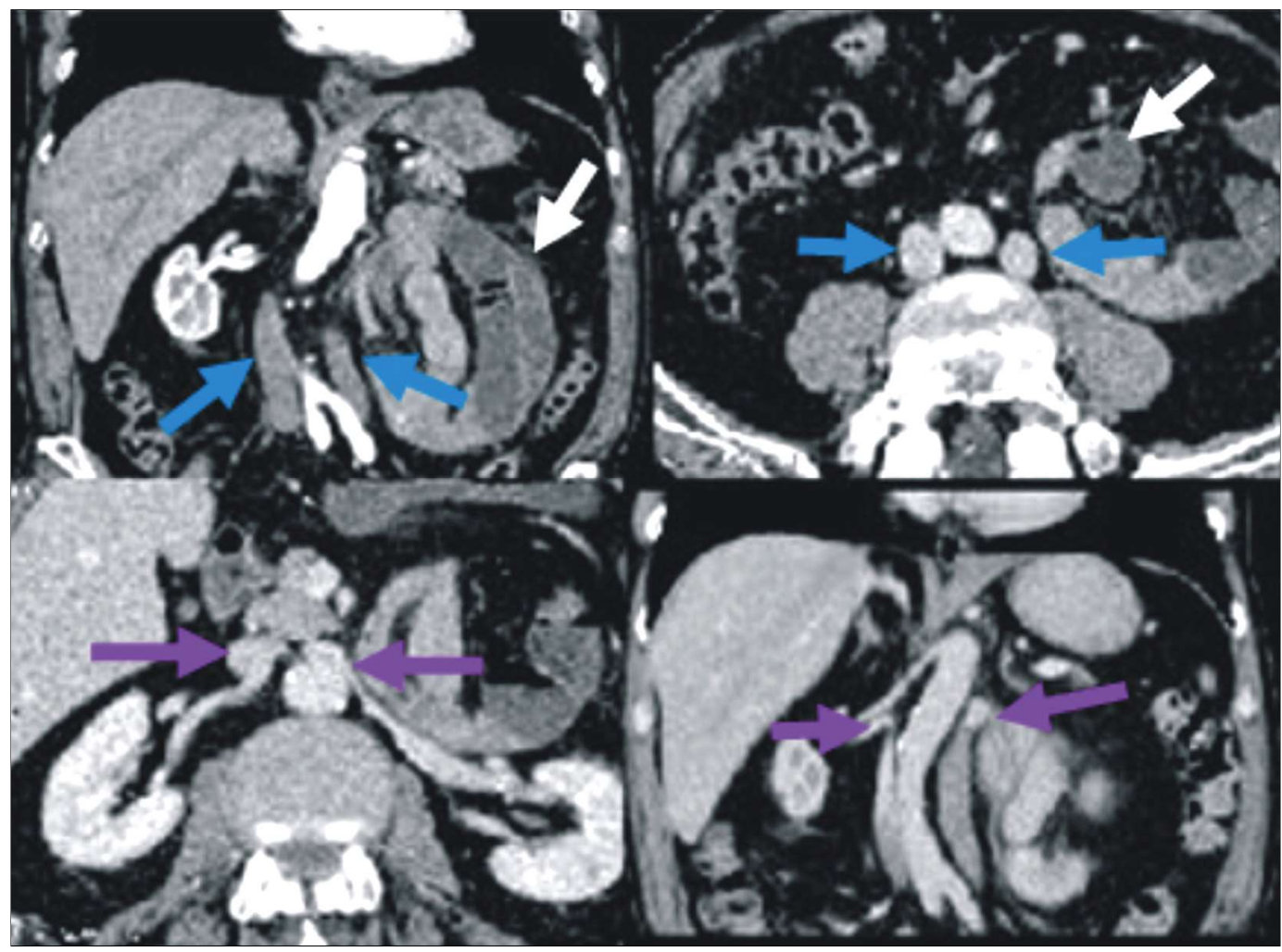

Figure1. Above: LPDH (white arrow) and DIVC (blue arrows). Below: each of the renal veins draining in its homolateral IVC

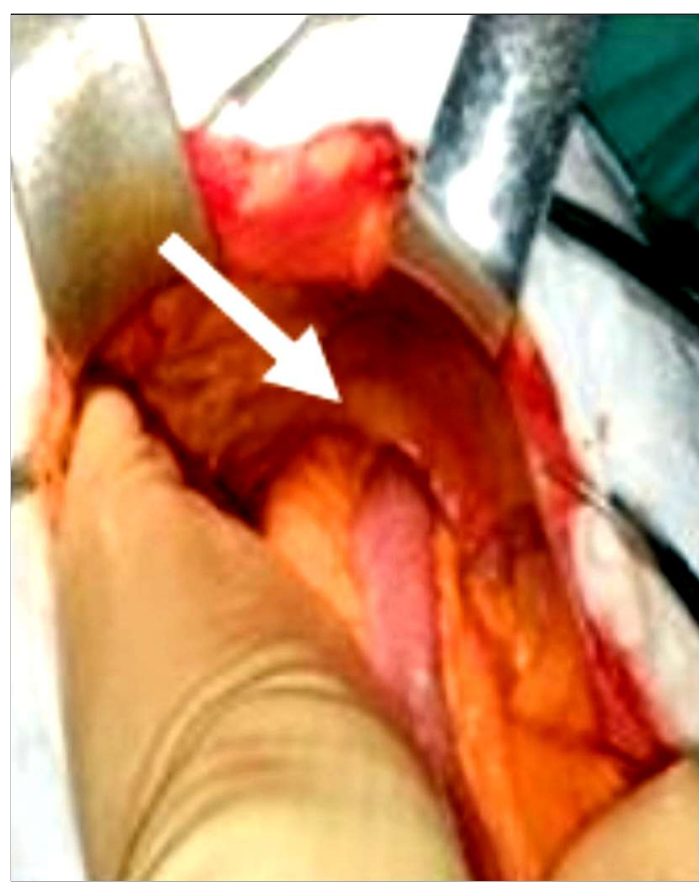

Figure2. $\quad \mathrm{LPDH}$

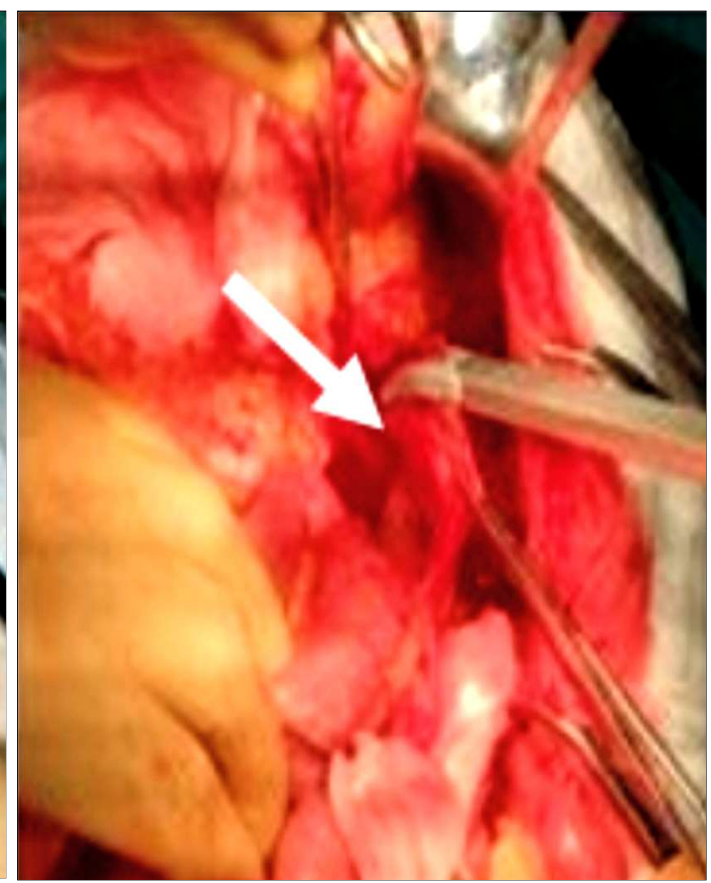

Figure 3. LPDF 
vein, left IVC, the absence of the hepatic segment of IVC (4). After a thorough review of the literature Nastis $\mathrm{K}$ et al. render the following classification of DIVC: type I or major duplication with two bilaterally symmetrical trunks with a preaortic trunk of the same caliber, type II or minor duplication with two bilaterally symmetrical trunks, but smaller than the preaortic trunk, type III or asymmetric duplication with small left IVC, larger right IVC and even larger preaortic trunk. They go on describing the second theory or the sacrocardinal theory that the chief role of the supracardinal veins is connected to the formation of the azygos and hemiazygos veins, when a new couple of veins or sacrocardinal veins (which are the last to form) is accredited the formation of the IVC instead. Still the formation of IVC remains unclear and complex (5). Shaha $\mathrm{P}$ et al. presents a case of a 22-year-old nulliparous female patient with intermittent abdominal pain for 5 months that intensified in the last 5 days prior to admission. Imaging revealed pyosalpinx with left ovarian cystic lesion, DIVC with crossed fused renal ectopia with a monourether and malrotation of the gut. The team observed DIVC is associated with genitourinary malformations such as pyelouretheric dilatation, retro-aortic left renal vein, circum-aortic renal vein known as 'venous collar', cloacal exstrophy and horseshoe kidney (6). Coskun A et al. presents a case of a 16-year-old patient with progressive dysmenorrhea, pelvic pain in the first years after menarche and persistent vaginal spotting after menstruation. Imaging revealed uterus didelphys with obstructed unilateral vagina, ipsilateral renal agenesis, DIVC high-riding aortic bifurcation and malrotation of the gut (7).

Embryologically, the malrotation of the gut is the $270^{\circ}$ complete or partial failure of counterclockwise rotation of the midgut around the superior mesenteric pedicle (8). The fossa of Landzert is located between the fourth part of the duodenum, the posterior peritoneum, the inferior mesenteric vein, and left branches of the middle colic artery. It is formed when the lower mesentery with the parietal peritoneum fail to fuse, develops into the descending and transverse mesocolon causing a failure of rotation of the bowels which tend to be entrapped through this unusual aperture of the colonic mesentery $(9,10)$. Welch classifies IH in eight main types according to the entrapped abdominal content and according to the location of the orifice ranking the LPDH as first in the list:1a: LPDH, 1b: right PDH, 2: foramen of Winslow hernia; 3: pericaecal hernia; 4: sigmoid-mesocolon-related hernia; 5: :transmesenteric hernia; 6: transomental hernia; 7:supravesical and pelvic hernia (11). Pathophysiologically, it is believed that Neubauer was the first to describe PDH stating that the main cause is a defect in peritoneal development, after whom Treitz described folds and fossae through which retroperitoneal hernias occur. Added to that, there are two interesting theories as to how PDH occur: Moynihan's theory states the return of the bowel back to the abdominal cavity and the fusion of the dorsal mesentery with the posterior abdominal wall generate a condition known as "physiological adhesions" which causes the development of folds and fossae with Landzert fossa and Waldeyer fossa being the two major ones which "gradually enlarge" causing the formation of PDH but Andrews' theory questioned the gradual enlargement of the fossae even though he agrees with the folds and fossae fusion theory, attributing the condition to the fusion faults of peritoneum, which entrap the small bowel under the maturing colon (12).

There is no specific treatment of DIVC. It is asymptomatic, is diagnosed incidentally or when such patients develop complications associated with concomitant congenital malformations such as abdominal and/or pelvic pain due to intestinal obstruction, genitourinary complications (trauma of the ectopic kidney, hydronephosis, pyelourether), dysmenorrhea. Garg MK et al. reported a case of a 43-year-old male patient with deep venous thrombosis (DVT) due to the varied coagulation mutations and was incidentally diagnosed with DIVC when performing catheter-directed thrombolysis with prophy- 
lactic IVC filter placement. Phlebography is deemed the "gold standard" for diagnostic but it is invasive (13). It is done only when fluoroscopy-guided catheter-directed thrombolysis is intended otherwise a routine CT-scan is enough (14). Because DVT seems to be directly associated with DIVC because of retrograde stasis, therefore an iliocaval stent is recommended in patients with nonthrombotic iliac vein injuries, in those with longlasting post-thrombotic iliocaval illness with poor quality of life and in those with a remaining thrombosis after thrombolysis for acute DVT (15).

\section{Conclusions}

DIVC is a rare congenital malformation which is incidentally diagnosed and must be dealt with thoroughly and carefully especially during vascular or urological surgeries, interventional radiology. Because it is mostly asymptomatic, it is oftentimes diagnosed after early or late onset of complications of associated congenital malformations. DVT seems to be closely linked to DIVC. Genitourinary congenital malformations are the most common associated congenital malformations with DIVC and in rare cases with malformation of the gut i.e. malrotation of the gut. DIVC is diagnosed during a routine CT-scan but can also be diagnosed during phlebography and does not require any specific treatment but only that of complications of associated congenital malformations. After reviewing the literature, we conclude correlation is not causation, DIVC and LPDH are two separated entities with two separate embryological origins that happen to be diagnosed at the same time. Although our patient had a medical history of varicose veins, he didn't report having DVT in the past.

\section{Conflicts of Interest}

The authors declare no conflict of interest.

\section{Financial Support}

This article was sponsored for publication by Thoma Ionescu Fundation.

\section{References}

1. Spentzouris G, Zandian A, Cesmebasi A, Kinsella CR, Muhleman M, Nadine Mirzayan, et al. The clinical anatomy of the inferior vena cava: A review of common congenital anomalies and considerations for clinicians. Clin Anat. 2014;27(8):1234-43.

2. González J, Gaynor JJ, Albéniz LF, Ciancio G. Inferior vena cava system anomalies: surgical implications. Curr Urol Rep. 2017; 18(2):10.

3. Tamizifar B, Seilani P, Zadeh MR. Duplication of the inferior vena cava and thrombosis: A rare case. J Res Med Sci. 2013;18(10): 911-3.

4. Bedel C, Türkoğlu S. Duplication of The Inferior Vena Cava: A Rare Case. Medical Journal of Western Black Sea. 2019;3(2):66-69

5. Natsis K, Apostolidis S, Noussios G, Papathanasiou E, Kyriazidou A, Vyzas V. Duplication of the inferior vena cava: anatomy, embryology and classification proposal. Anatomical Science International. 2009;85(1):56-60.

6. Shaha P, Garg A, Sahoo K, Kothari N, Garg P. Duplication of inferior vena cava with associated anomalies: a rare case report. J Clin Diagn Res. 2016;10(3):TD01-TD4.

7. Coskun A, Okur N, Ozdemir 0, Kiran G, Arykan DC. Uterus didelphys with an obstructed unilateral vagina by a transverse vaginal septum associated with ipsilateral renal agenesis, duplication of inferior vena cava, high-riding aortic bifurcation, and intestinal malrotation: a case report. Fertil Steril. 2008;90(5): 2006.e9-11

8. Bhatia S, Jain S, Singh CB, Bains L, Kaushik R, Gowda NS. Malrotation of the Gut in Adults: An Often Forgotten Entity. Cureus. 2018;10(3):e2313.

9. Kozman MA, Fisher OM. Left paraduodenal hernia: a rare complication following laparoscopic appendectomy. Case Reports in Surgery. 2017;2017:1-3.

10. Abukhalaf SA, Mustafa A, Elqadi MN, Al Hammouri A, Abuzaina K NM, Abukarsh R, et al. Paraduodenal hernias in children: Etiology, treatment, and outcomes of a rare but real cause of bowel obstruction. Int J Surg Case Rep. 2019;64:105-108.

11. Murali Appavoo Reddy UD, Dev B, Santosham R. Internal hernias: surgeons dilemma-unravelled by imaging. Indian J Surg. 2014; 76(4):323-8. Epub 2012 Jul 26.

12. Majdoub KI, Aggouri Y, Laalim SA, Toughrai I, Mazaz K. Left paraduodenal hernia: a rare cause of acute abdomen. Pan Afr Med J. 2014:17:230

13. Wang X, Chen Z, Cai Q. Catheter-directed thrombolysis for double inferior vena cava with deep venous thrombosis: a case report and literature review. Phlebology. 2014;29(7):480-3. Epub 2013 May 17.

14. Garg MK, Satwik A, Bedi VS, Uppinakudru G, Agarwal S, Yadav A. Duplication of inferior vena cava and coagulation mutations with left-sided iliofemoral venous thrombosis. J Vasc Surg Cases Innov Tech. 2018;5(1):26-30

15. Mahnken AH, Thomson K, de Haan M, O'Sullivan GJ. CIRSE standards of practice guidelines on iliocaval stenting. Cardiovasc Intervent Radiol. 2014;37(4):889-97. 